Vol 1. No. 3, Juli 2021 P-ISSN : 2774-8030, e-ISSN : 2774-8030

\title{
HUBUNGAN IKLIM ORGANISASI DAN EFEKTIVITAS KEPEMIMPINAN DENGAN KINERJA GURU SMP ISLAM DARUSSALAM LOMBOK
}

\author{
MUHAMAD SUHARDI \\ Fakultas Ilmu Pendidikan Undikma \\ e-mail: ardhysmart7@gmail.com
}

\begin{abstract}
The purpose of this study was to determine the relationship between organizational climate and leadership effectiveness on the work performance of teachers of SMP Islam Darussalam Lombok. The research methodology is a survey selected by simple random sampling technique. Analysis and interpretation of the data shows that (1) organizational climate has a positive direct relationship with job performance, (2) effectiveness has a positive effect on work performance, (3) organizational climate has a positive direct relationship with leadership effectiveness.

Keywords: organizational climate, effectiveness leadership, job performance.
\end{abstract}

\begin{abstract}
ABSTRAK
Tujuan penelitian ini adalah untuk mengetahui hubungan iklim organisasi dan efektivitas kepemimpinan terhadap prestasi kerja guru SMP Islam Darussalam Lombok. Metodologi penelitian adalah survei yang dipilih dengan teknik simple random sampling. Analisis dan interpretasi data menunjukkan bahwa (1) iklim organisasi memiliki hubungan langsung positif dengan kinerja pekerjaan, (2) efektivitas berpengaruh positif terhadap prestasi kerja, (3) iklim organisasi memiliki hubungan langsung positif dengan efektivitas kepemimpinan.
\end{abstract}

Kata Kunci: iklim organisasi, efektivitas kepemimpinan, prestasi kerja

\section{PENDAHULUAN}

Era globalisasi membuka segala akses dalam setiap aspek kehidupan manusia. Setiap bangsa berusaha menampilkan produk terbaiknya untuk bersaing dalam perdagangan bebas. Selain itu semakin tercipta hubungan kerjasama regional yang baik. Hal ini memerlukan manusia-manusia yang berkualitas yaitu manusia yang kompetitif, kreatif dan inovatif. Sekolah yang efektif memegang peranan strategis untuk mewujudkannya.

Sekolah yang efektif adalah sekolah yang menghasilkan tingkat kelulusan yang tinggi dengan kualitas lulusan yang baik. Hal ini dapat diukur dari banyaknya alumni yang memasuki dunia kerja ditempat-tempat yang strategis. Namun hal ini tidak terlepas dari input yang diterima sekolah itu yang berupa dana, sumber daya manusia seperti guru dan tenaga administrasi sekolah dan manajemen yang efektif. Untuk mencapai kinerja sekolah yang tinggi memerlukan pembiayaan yang cukup besar, hal ini menjadi masalah yang besar khususnya untuk sekolah-sekolah swasta yang dikelola oleh yayasan. Masalah ini pernah ditulis di harian Kompas dengan kutipan langsung sebagai berikut : "ketika keuangan pemerintah masih terbatas, sekolah-sekolah swasta di sejumlah daerah berperan besar dalam penyelenggaraan pendidikan dan upaya mencerdaskan bangsa. Ironisnya ketika anggaran pemerintah untuk pendidikan sudah memadai, peran sekolah swasta justru dipinggirkan dengan beragam cara, mulai dari produk undang-undang sampai dengan kuota sertifikasi yang menyudutkan sekolah-sekolah swasta". Oleh karena itu diperlukan strategi yang baik dan manajemen yang efektif agar sekolah swasta tetap eksis sehingga kinerja tidak berkurang, Karena kinerja sekolah merupakan hasil yang nyata dari suatu proses penyelenggaraan pendidikan.

Kinerja dalam dunia pendidikan berkaitan dengan keseluruhan proses perencanaan, penataan dan pendayagunaan sumber daya untuk merealisasikan tujuan pendidikan secara efektif dan efisien. Sejauh mana pencapaian kinerja pendidikan dapat dilihat dari out put pendidikan yang berupa prestasi, serta proses pendidikan yang berupa suasana pendidikan. Prestasi dapat dilihat dari 
masukan yang merata baik dari segi jumlah maupun kualitas peserta didik, jumlah tamatan yang banyak, mutu tamatan yang tinggi, relevansi yang tinggi dengan pekerjaan yang akan dihadapi untuk berpenghasilan yang baik. Sedangkan proses atau suasana tampak dalam kegairahan belajar, dan semangat kerja yang tinggi serta kepercayaan dari berbagai pihak

Kinerja diukur dari input dan output. Input berupa sumber-sumber daya atau masukan yang digunakan dan output berupa hasil proses seperti tingkat kelulusan, jumlah siswa yang berhasil diterima kerja atau kuliah ditempat favorit tertentu. Tingkat kelulusan SMP swasta di Lombok dapat di lihat dari table lampiran. Terlihat bahwa ada sekolah yang dapat meluluskan siswanya 100 \%,seperti SMP Penabur, SMP Regina Pacis, SMP Notredam dan lainnya yang berjumlah 28 sekolah swasta dari 84 peserta UN dari sekolah swasta tahun 2011, selebihnya tidak dapat meluluskan $100 \%$, bahkan ada sekolah persentase tidak lulusnya mencapai $92,8 \%$. Kelulusan dalam UN adalah salah satu indikator kinerja dari suatu sekolah yang merupakan output dari suatu proses pembelajaran di sekolah. Selain itu tingkat masukan siswa juga merupakan indicator tingginya kinerja sekolah itu , karena sekolah yang diminati adalah sekolah dinilai oleh masyarakat dapat memenuhi keinginan mereka sesuai dengan perkembangan zaman.

Tingkat masukan siswa di sekolah swasta di Lombok lebih banyak mengalami penurunan,rata-rata sebesar $25 \%$. Hanya sedikit sekolah yang mendapatkan kenaikan jumlah siswa. Penurunan jumlah siswa masuk ke sekolah swasta hampir merata diseluruh Lombok. Penyebabnya antara lain karena kurang patuhnya sekolah negeri melaksanakan peraturan menteri no. 23 tahun 2005 tentang syarat jumlah peserta didik, sehingga menyerap jumlah siswa yang masuk. Selain itu pengangkatan guru yang semrawut, dimana selain Kementerian Pendidikan dan Kebudayaan, Kementerian Agama, pemerintah kabupaten/kota juga ikut-ikutan mengangkat guru. Akibatnya jumlah guru di kota-kota khususnya guru PNS cukup besar sementara itu guru mendapatkan jumlah jam mengajar yang sedikit. Oleh karena itu untuk mengimbanginya, kuota siswa masuk ditambah dan jumlah kelas ditambah.

Jumlah sekolah negeri setingkat SMP di Lombok ada 115 sekolah dari jumlah seluruhnya yaitu 460 sekolah Jadi jumlah sekolah negeri hanya berkisar $25 \%$ dari jumlah seluruh sekolah yang ada di LOMBOK. Hal ini dapat menjadi gambaran jumlah sekolah negeri di Indonesia lebih kecil dari jumlah sekolah swasta, namun jumlah guru yang statusnya diluar guru yayasan lebih besar yaitu 2.613.967 guru, atau sekitar 89,3\% dari jumlah seluruh guru yaitu 2.928.322. Dari data ini dapat dikatakan bahwa sekolah swasta merupakan penyumbang terbesar pendidikan di Indonesia, bahkan mungkin dunia, namun karena keterbatasan biaya dan minimnya bantuan pemerintah, banyak sekolah swasta terpaksa tutup atau melakukan penggabungan dengan sekolah lain. Sementara itu karena berkaitan dengan biaya, sekolah swasta mengurangi jumlah guru bahkan banyak sekolah yang mewajibkan gurunya mengajar bidang study yang tidak relevan dengan pendidikannya untuk memenuhi syarat jam mengajar. Telah terjadi kesenjangan yang begitu dalam, disatu sisi terjadi kelebihan disisi lain kekurangan. Hal ini dapat mempengaruhi kinerja sekolah swasta, karena sekolah swasta sangat tergantung pada partisipasi siswa terutama dalam hal pembiayaan yang merupakan input dari penyelengaraan proses pembelajaran. Oleh karena itu perlu dicari faktor-faktor yang mempengaruh kinerja di sekolah tersebut.

Banyak faktor yang mempengaruhi kinerja pada suatu sekolah, antara lain faktor efektivitas kepemimpinan kepala sekolah dan komunikasi yang terjadi dalam lingkungan kerja di sekolah. Efektivitas kepemimpinan terjadi jika kepala sekolah mempunyai kemampuan dalam memimpin anggotanya, kemampuan konseptual dan hubungan manusiawi, mampu berkomunikasi dengan guru maupun pihak atasan, mampu menilai kinerja guru dan staf administrasi, kemampuan menganalisis masalah, mengambil keputusan secara cepat dan tepat. Efektivitas kepemimpinan kepala sekolah diukur dari kemampuannya memotivasi guru untuk bersama-sama bertanggungjawab menghasilkan kelulusan $100 \%$, dan kualitas lulusan yang baik sehingga menjadi nilai jual untuk mendapatkan masukan siswa yang banyak 
Berdasarkan uraian di atas maka dianggap masalah kinerja yang dihubungkan dengan efektivitas kepemimpinan dan efektivitas kepemimpinan dari guru penting untuk diteliti, khususnya pada SMP swasta di Lombok. Oleh karena itu penulis merumuskan judul "Hubungan Efektivitas Kepemimpinan dan efektivitas kepemimpinan dengan Kinerja guru SMP Swasta di Kecamatan Pademangan, Lombok.

\section{Kinerja}

Sebelum membahas tentang hal-hal yang berhubungan dengan kinerja pegawai, terlebih dahulu membahas tentang pengertian kinerja. Istilah kinerja berasal dari kata job perfomance atau actual performance adalah prestasi kerja atau prestasi sesungguhnya yang dicapai seseorang atau sekelompok orang yang ada dalam suatu organisasi sesuai dengan wewenang dan tanggungjawab masing-masing dalam upaya pencapaian tujuan organisasi Jason A. Colquitt, J. LePine, dan Michel J. Weson (2015:32) berpendapat, "job performance is formally defined as the value of the set of employee behaviors that contribute, either positivly or negativly, to organizational goal accomplishment". Kinerja adalah secara umum adanya seperangkat nilai yang memberikan kontribusi prilaku karyawan secara positif atau negatif untuk mencapai tujuan organisasi.

Selanjutnya John M.Ivancevich, Robert Konopaske, Michael T. Matteson (2014:172), “job performance a set of employee work related behavior designed to accomplish organizational goals". Kinerja adalah seperangkat perilaku yang berhubungan dengan pekerjaan karyawan dirancang untuk mencapai tujuan organisasi. Sementara itu Chuck Williams (2011:493) bahwa, "job performance is how well someone performs the requirements of the job". Kinerja adalah seberapa baik seseorang melaksanakan kebutuhan pekerjaan tersebut. Sedangkan Leslie W. Rue, dan Lloyd L. Byars (2008:216), mengatakan bahwa, “job performance is the net of an employee's effort as modified by abilities and role (or task) perceptions. Thus, performance in a given situation can be viewed as resulting from the inter-relationship". Kinerja adalah upaya karyawan yang terkait dengan kemampuan dan peran atau tugas yang di persepsikan. Dengan demikian, kinerja dalam situasi tertentu dapat dilihat sebagai akibat dari hubungan timbal balik.

John R. Schemerhorn, JR, Paul Davidson. David Poole, Peter Woods, Alan Simon, Ellen McBarron (2014:459), "job performance is the quantity and quality of task accomplishment by an individual or group". Kinerja adalah kuantitas dan kualitas penyelesaian tugas oleh individu atau kelompok. Selanjutnya Aguinis (2009:2) juga mendefinisikan, "performance is a continuous process of identifying, measuring, and developing the performance of individuals and teams and aligning performance with the strategic goals of the organization". Kinerja merupakan proses yang berkesinambungan untuk mengidentifikasi, mengukur, dan mengembangkan kinerja individu dan tim dan menyelaraskan kinerja dengan tujuan strategis organisasi.

Dari uraian di atas dapat disintesiskan kinerja adalah perilaku yang berhubungan dengan pekerjaan seseorang yang dirancang untuk mencapai tujuan organisasi dengan indikator: perilaku dalam bekerja, ketaatan dan tanggung jawab.

\section{Iklim Organisasi}

Iklim organisasi adalah suasana di tempat kerja, yang membedakannya dari tempat kerja yang lain. Iklim organisasi menggambarkan lingkungan internal organisasi dan berakar pada budaya organisasi serta bersifat relatif sementara dan dapat berubah dengan cepat Istilah iklim organisasi (organizational climate) pertama kalinya dipakai oleh Kurt Lewin pada tahun 1930-an, yang menggunakan istilah iklim psikologi (psychological climate) yang kemudian berkembang dan dipakai oleh para ahli berikutnya. Iklim organisasi menggambarkan lingkungan internal organisasi dan berakar pada budaya organisasi serta bersifat relatif sementara dan dapat berubah dengan cepat, Robert Ivancevich yang dikutip oleh Michael Armstrong (2008:385) mendefinisikan iklim organisasi sebagai berikut; "organizational climate is a set of properties of the work environment, 
perceived directly or indirectly by the employees, that is assumed to be a major force in influencing employee behaviour. Iklim organisasi adalah seperangkat sifat lingkungan kerja, dirasakan secara langsung atau tidak langsung oleh karyawan, yang diasumsikan menjadi kekuatan utama dalam mempengaruhi perilaku karyawan. Selanjutnya Denison yang dikutip oleh Stephen P. Robbins dan Timothy (2013:516) menyatakan bahwa,"organizational climate refers to the shared perceptions organizational members have about their organization and work environment". Iklim organisasi mengacu pada persepsi bersama anggota organisasi tetang apa yang mereka memiliki di sekitar organisasi dan lingkungan kerja mereka.

Pengertian iklim organisasi yang lain dikemukakan oleh Robert N. Lussier (2013:386) sebagai berikut: "organizational climate is the relatively enduring quality of internal environment of the organization as perceived by its members. Climate is employees perception of the atmosphere of the internal environment". Iklim organisasi adalah kualitas yang relatif abadi pada lingkungan internal organisasi seperti yang dirasakan oleh anggotanya. Iklim adalah persepsi karyawan terhadap suasana lingkungan internal.

Berdasarkan uraian di atas, yang dapat disintesiskan iklim organisasi adalah suasana di sekitar tempat kerja yang menunjang pelaksanaan pekerjaan dan dirasakan langsung atau tidak langsung oleh pegawai yang mempengaruhi perilaku kerjanya di dalam organisasi dengan indikator, lingkungan kerja, pola perilaku karyawan, dan persepsi rasa memiliki terhadap organisasi

\section{Efektivitas Kepemimpinan}

Kepemimpinan memainkan peranan yang amat penting, bahkan dapat dikatakan amat menentukan dalam usaha pencapaian tujuan yang telah ditetapkan dalam suatu organisasi.

Untuk bisa mempengaruhi setiap individu agar dapat melakukan tugas-tugas organisasi diperlukan pemimpin yang efektif.dan pemimpin yang kuat . Efektivitas kepemimpinan menurut Gary Yukl (2006:12) adalah, "leader effectiveness is occasionally measured in terms of the leader's contribution to the quality of group processes, as perceived by followers or by outside observers". Efektivitas kepemimpinan merupakan ukuran tentang seberapa jauh unit organisasi pemimpin tersebut berhasil menunaikan tugas pencapaian sasarannya. Effektivitas pemimpin terkadang diukur berdasarkan konstribusi pemimpin pada kualitas proses kelompok yang dirasakan oleh para pengikut atau pengamat dari luar. Tersirat dalam definisi ini efektivitas kepemimpinan merupakan kualitas pemimpin untuk dapat memotivasi orang lain dan percaya kepadanya sehingga setiap orang berusaha melaksanakan tugasnya untuk mencapai tujuan organisasi. Seperti definisi kepemimpinan, konsep pemimpin yang efektif juga berbeda antara satu pakar dengan pakar lainnya. Yang pertama peneliti kemukakan pendapat Schermerhorn (2005:11), "an effective manager is one whose organizational unit, group, or team consistently achieves its goals while members remain capable, committed, and enthusiastic". Pemimpin efektif adalah yang unit organisasi, kelompok, atau timnya secara konsisten mencapai tujuannya sementara para anggotanya tetap memiliki kemampuan, komitmen, antusias dan bersemangat.

Sementara itu menurut Nanus and Dobbs yang dikutip oleh Syarifuddin (2010:109) menjelaskan bahwa, "leadership effectiveness it means producing a greater social good usually by increasing organizational capital or creating harnessing social energy". Kepemimpinan efektif adalah menghasilkan kemaslahatan sosial yang sangat banyak, dengan meningkatkan modal organisasi atau mendapatkan pemanfaatan energi sosial. Kemudian Susan E. Jackson, Randall S. Schuler, Steve Werner (2009:56) berpendapat bahwa, "effective leadership ensures that people are generally working to achieve the same results". Kepemimpinan yang efektif memastikan atau menjamin orang-orang secara umum mencapai hasil yang sama.

Dari uraian tersebut dapat disintesiskan efektivitas kepemimpinan adalah keberhasilan pemimpin di dalam menunaikan tugas untuk pencapaian sasaran dengan indikator: tugas 
pemimpin, kepribadian pemimpin, hubungan pemimpin dengan karyawan, pemimpin sebagai dari organisasi.

\section{METODE PENELITIAN}

Penelitian ini menggunakan metode survey dengan teknik korelasi Data penelitian ini dikumpulkan dengan cara memilih sampel dalam populasi. Populasi terjangkau dalam penelitian ini adalah seluruh guru SMP swasta yang berjumlah 174 guru. Dan perhitungan dengan menggunakan slovin, maka di peroleh jumlah sampel sebanyak 121 guru SMP swasta Lombok yang dijadikan sampel frame dalam penelitian ini. Pengumpulan data digunakan untuk penelitian ini adalah statistika deskriptif dan statistika inferensial.

\section{HASIL DAN PEMBAHASAN}

\section{Hubungan iklim organisasi dengan kinerja.}

Hasil pengujian hipotesis pertama dapat disimpulkan bahwa terdapat hubungan positif antara iklim organisasi dengan kinerja, dimana koefisien korelasi sebesar 0,557 menghasilkan thitung $=7,31$ lebih besar dari ttabel $=2,62$ pada $\alpha=0,01$. Kesimpulan tersebut menunjukkan bahwa semakin tinggi iklim organisasi, maka akan semakin tinggi pula kinerja.

Korelasi antara iklim organisasi dengan kinerja menunjukkan kebermaknaannya, baik melalui korelasi product moment maupun korelasi parsial. Hasil analisis ini memberikan petunjuk bahwa iklim organisasi merupakan salah satu faktor utama yang berkonstribusi terhadap kinerja. Dari hasil itu pula dapat diinterpretasikan bahwa peningkatan iklim organisasi akan memberikan konstribusi yang berarti terhadap kinerja. Hal ini sesuai dengan pendapat Laurie J. Mullins (2010:925) menyatakan bahwa, "applied to organisations, climate can be said to relate to the prevailing atmosphere surrounding the organisation, to the level of morale, and to the strength of feelings or belonging, care and goodwill among members. Climate will influence the attitude which members of the organization bring to bear on their work performance and personal relationships". Iklim dapat dikatakan sesuatu yang berhubungan dengan suasana yang berlaku di sekitar sekolah, tingkat moral, dan kekuatan perasaan atau rasa memiliki, kepedulian dan niat baik di antara anggota. Iklim akan mempengaruhi sikap guru terhadap kinerja dan hubungan pribadi antar guru.

\section{Hubungan efektivitas kepemimpinan dengan kinerja}

Hasil pengujian hipotesis kedua dapat disimpulkan bahwa terdapat hubungan positif antara efektivitas kepemimpinan dengan kinerja, dimana koefisien korelasi sebesar 0,549 menghasilkan thitung $=7,16$ lebih besar dari ttabel $=2,62$ pada $\alpha=0,01$. Kesimpulan tersebut menunjukkan bahwa semakin tinggi efektivitas kepemimpinan, maka akan semakin tinggi pula kinerja.

Hal ini sesuai dengan pendapat John P.Howell dan Dan L. Costley (2001:25) juga menyatakan:'the real objective of effective leadership is to influence followers' behaviors and outcomes. Important outcomes include high individual and group performance; low turnover, absenteeism, lateness and grievance rates; and high quality levels, all of which result in a productive Organization". Kutipan ini menjelaskan bahwa tujuan sesungguhnya dari kepemimpinan yang efektif adalah untuk mempengaruhi perilaku pengikut dan hasil pekerjaan. Hasil penting termasuk penampilan guru dan kinerja kelompok, pendapatan yang rendah, ketidakhadiran, keterlambatan, mengukur tingkat keluhan, dan tingkat kualitas yang tinggi, yang semuanya menghasilkan sebuah organisasi yang produktif.

\section{Hubungan antara iklim organisasi dan efektivitas kepemimpinan Secara Bersama-sama dengan Kinerja}

Hasil pengujian hipotesis ketiga dapat disimpulkan bahwa iklim organisasi dan efektivitas kepemimpinan secara bersama-sama mempunyai hubungan positif dengan kinerja. Koefisien 
korelasi ganda antara kedua variabel bebas dengan variabel terikat Ry.12 sebesar 0,678 meghasilkan Fhitung $=50,32$ lebih besar dari Ftabel $=4,79$ pada $\alpha=0,01$. Dari koefisien korelasi tersebut, dapat dihitung koefisien determinasi (Ry.12)2 sebesar 0,4603 berarti bahwa 46,03\% proporsi varians kinerja dapat dijelaskan secara bersama-sama oleh iklim organisasi serta efektivitas kepemimpinan.

Hal ini sesuai dengan pendapat Mullins (2010:925) menjelaskan: "organisational climate is characterised, therefore, by the nature of the people-organisation relationship and the superiorsubordinate relationship. These relationships are determined by interactions among goals and objectives, formal structure, the process of management, styles of leadership and the behaviour of people". Iklim organisasi merupakan suatu karakter yang ditandai berdasarkan sifat hubungan manusia dengan organisasi dan hubungan pimpinan dan pengikut. Hubungan ini ditentukan oleh interaksi antara tujuan, sasaran, struktur formal, proses manajemen, gaya kepemimpinan dan perilaku bawahan.

\section{KESIMPULAN}

Dari hasil penelitian yang dilakukan didapatkan kesimpulan sebagai berikut :

1) Iklim organisasi berhubungan positif dengan kinerja. Artinya semakin kondusi ikim organisai maka semakin baik kinerja guru SMP swasta di Kecamatan Pademangan.

2) Efektivitas kepemimpinan berhubungan positif dengan kinerja. Artinya, semakin efektitif kepala sekolah dalam memimpin sekolah, maka semakin baik kinerja kinerja guru SMP swasta di Kecamatan Pademangan.

3) Iklim organisasi dan efektivitas kepemimpinan secara bersama-sama berhubungan positif dengan kinerja. Artinya semakin kondusif iklim organisasi dan semakin meningkat efektivitas kepemimpinan secara bersama-sama, maka semakin baik kinerja kinerja guru SMP swasta di Kecamatan Pademangan.

\section{DAFTAR PUSTAKA}

Armstrong, Michael. (2008). Armstrong's Handbook: of Human Resource Management Practice, Eleventh Edition. London and Philadelphia: Kogan Page.

Byars, Lloyd L., Leslie W. Rue. (2004). Human Resource Management 7 edition. New York: McGraw-Hill.

Colquitt, Jason A. J. LePine, Michel J. Weson. (2015). Organization Behavior, Improving Performance and Commitment in Workplaces 4 edition. New York: McGraw-Hill.

George, Jennifer M., Gareth R. Jones. (2005). Understanding and Managing Organizational Behavior. New Jersey: Pearson Prentice Hall.

Gibson, James L., James H. Donnelly, Jr, John M. Ivancevich, Robert Konopaske. (2012). Organizational Behavior Structure Process 14 edition. New Yok: McGraw-Hill.

Howell, John P. dan L. Costley. (2001). Undertanding Behaviors for Effective Leadership (New Jersey: Prentice Hall.

Hughes, Richard L., Robert C. Ginnett, Gordon J. Curphy. (2009). Leadership: Enhancing the Lessons of Experience, 6 edition. New York: McGraw-Hill Education,.

Jackson, Susan E., Randall S. Schuler, Steve Werner. (2009). Managing Human Resources, International Student Edition. Canada: South-Western Cengage Learning.

Jex, Steve M. (2002). Organizational Psychology. USA: John Wiley

Locke, Edwin A. (2009). Handbook of Principles Of Organizational Behavior 2 edition. United Kingdom: Wiley \& Son.

Lussier, Robert N. (2013). Human Relations in Organizational Application and Skills Building 9 Edition. New York: Mc.Graw-Hill 
Mullins, Laurie J. (2010)). Essentials of Organisational Behaviour 9 edition. Harlaow: Pearson Education Limited

Owens, Robert G. (1995). Organizatoinal Behavior in Education. Boston: Allyn and Bacon.

Plunkett, Warren R., Raymond F. Attner, Gemmy S. Allen. (2008). Management: Meeting and Exceeding Customer Expectation. USA: Thomson Corporation, Ninth Edition.

Puccio, Gerard J., Mar C. Murdock, Marie Mance. (2007). Creative Leadership Skill That Drive Change. California: Sage Publication.

Robbins, Stephen P., Timothy A. Judge. (2015). Organizational Behavior. New Jersey : Pearson EducationInc.

Robbins. Stephen P., Timothy A. Judge. (2013). Organizational Behavior, 15 Edition. New Jersey: Pearson Education, Inc.

Schermerhorn, John R. James G. Hunt, and Richard N. Osborn. (2005). Organizational Behavior, Ninth Edition . USA: John Wiley \& Sons, Inc.

Syafaruddin. (2010). Kepemimpinan Pendidikan. Jakarta: Quantum Teaching.

Williams, Chuck. (2011). Management 6 edition. USA: South Western Cengange Learning.

Yukl, Gary A. (2006). Leadership in Organizational. New Jersey : Pearson Prentice Hall. 